\title{
Turkey's Efforts to Fight Human Trafficking in the Black Sea Region: A Regional Approach
}

\section{Marielle Sander Lindstrom *}

The Black Sea region, with more than twelve major nations and thousands of kilometers of coastline, is still struggling to achieve sustained economic prosperity. To the north, the former states of the Soviet Union remain in transition, or are stuck in cycles of despair and poverty. To the south, Turkey has emerged as an engine of relative prosperity, particularly for the tens of thousands of labor migrants that flow across its borders every year. This dynamic region, with its striking disparity between rich and poor, is now situated at the center of a major fight to combat human trafficking. At the root of the problem is the acute poverty of the northern post-Soviet states. The citizens of these nations - notably Ukraine, Moldova, and Russia - are increasingly seeking entry into the Turkish economy, drawn by the false promise of financial gain. Strikingly, the push factors for the high rates of labor migration into Turkey are proving to be the same as those for trafficked individuals. ${ }^{1}$ The traffickers are exploiting the vulnerability of individuals who have few economic options, and are willing to take any chance to escape from communities with few jobs, and even fewer prospects for the improvement of one's standard of living. ${ }^{2}$

Since the beginning of 2005, the Turkish government has adopted an innovative regional approach to the problem of human trafficking. International Organization for Migration (IOM) field offices, media organizations, and local NGOs in Moldova, Ukraine, and Romania (statistically the main source countries for victims of trafficking in Turkey) are working together with the Turkish government to promote Turkey's own telephone helpline for victims of trafficking. The motivation for this is twofold. On the one hand, the Turkish authorities would like to encourage potential victims to verify the job opportunities that they have been offered by checking in with their national helplines, to find out whether or not the job offered actually exists. On the other hand, Turkey believes that if a person does fall prey to human traffickers in Turkey, they will be more likely to call a helpline number that they are already familiar with —as is being proven by the success of Turkey's 157 helpline. Strikingly, Turkey is the only major destination country to adopt such a radical approach in an effort to offer potential victims an avenue to escape if they find themselves in danger. By establishing trust from the very beginning, the Turkish authorities expect to increase the chances for collabora-

Marielle Sander Lindstrom is Chief of Mission at the International Organization for Migration, Ankara, Turkey. Opinions expressed in this article are those of the author and do not necessarily reflect the views of IOM.

1 Many victims of trafficking in Turkey, as in other countries, start off as part of a smuggling process, and end up in a situation of exploitation and human rights violation, hence becoming victims of trafficking.

2 Interviews with victims of trafficking in Turkey indicate that poor socio-economic conditions in their home countries are a strong push factor for them to seek work abroad. 
tion with the victims against the traffickers once they are apprehended. The lesson learned from the countries of origin in the past decade is that, while the root causes of human trafficking remain the same, significant efforts must be made regionally and internationally to protect the human rights of the victims and prosecute the traffickers.

\section{The Case of Moldova}

Moldova remains a major source country for victims of trafficking that are brought to Turkey for many reasons, with economic hardship being the main push factor. In a recent report on migration and remittances in Moldova, most emigrants interviewed cited the difficulty of earning a living wage as their main reason for emigrating. ${ }^{3}$ The Moldovan study reflects the situation of many citizens in the region, and is supported by statements from victims of trafficking from other countries that have been identified in Turkey. ${ }^{4}$ The desperate need for money drives individuals from transitional economies to look outside their own communities for work. With little or no reliable information on the realities of migration, most people turn to informal networks of family and friends who sometimes turn out to be traffickers to secure a job that will enable them to remit funds back to their home communities. It is not surprising to note that the most difficult issue for prospective emigrants is finding the money to fund their travel abroad. 51 percent of the respondents in the Moldovan study lacked the necessary funds for departure. Many borrowed money from black market lenders to cover these expenses, at 10 percent interest per month. If a migrant is deported from the destination country, he or she is still responsible for repaying the initial debt, so they have little choice but to go abroad again illegally. It is little wonder, then, that many turn to recruiters who can promise not only a job, but also a means to reach the destination country. Many of these people fall prey to traffickers.

Foreign remittances to Moldova in 2003 were estimated at USD 461 million (23.5 percent of GDP). Official estimates of the National Bank in Moldova show that gross remittances for 2004 grew to USD 701 million (27 percent of GDP). According to the same report, the majority of families with members who had emigrated mentioned that their situation improved after their migrant family member began supporting those left behind. As a result, their lifestyle improved, and many were, for example, able to receive proper medical treatment. Interviews with victims of trafficking in Turkey confirm this picture. Many Moldovans have no heat, running water, or access to social services. People in poor villages see what the money sent by successful emigrants can bring; they see that their neighbor has repaired his roof, and that his daughter has a new coat. Why should they not want the same? Most do not trust the press or their government, but they listen to stories from people who have been outside Moldova and who send money home. If they have no access to information on how to improve their life, if there are no jobs to be had, if economic development has not reached their village, then

3 IOM Moldova, "Migration and remittances in Moldova," European Commission Food Security Program, Moldova, International Monetary Fund Office in Moldova, July 2005.

4 IOM Turkey statistics and interviews with victim of trafficking, 2004-2005. 
people will listen to those who can promise them a chance for a better future. It is only after some time that the migrants become aware of the potential risks to themselves, and for some it is too late, as illustrated in the case study below, which is testimony from a thirty-one-year-old Moldovan woman:

I was born in Moldova in 1974 and have two living children. The economy is so bad there that when a friend offered me work in Turkey, I didn't hesitate to accept because I couldn't afford to support my family. I planned to work for a while and then come back and take care of my children. My friend took care of all the arrangements, the passport, the tickets, the visa, and took care of all the expenses. I was told that someone named Veysel would meet me at the Antalya airport and take me to my new job. I thought Veysel was someone that my new employer sent to help me. Instead, he took my passport and took me to a village. They took me to a house where there was a Moldovan woman who told me that I'd been brought here to work in the sex industry. I said I didn't want to do that and I wanted to go back home. They put a gun to my head and threatened me, and then they beat me. They told me if I didn't consent, they would kill me.

They kept me locked in the house and brought customers to me. There were a few other girls in the house, too. Once, when there were only three of us in the house, nine clients came. One girl took one client, the next girl took two men, and then I had to have the remaining six men. One day, the Moldovan woman took me to a hotel for a client. I called the La Strada hotline in my country and asked for help. La Strada told me to call 157, the helpline in Turkey. I called 157 and told the operator where I was and that I needed help. The 157 helpline operators called the Antalya police, and they came and rescued me. I was taken to a shelter in Istanbul. I wanted to go back home. I declared that I voluntarily wished to return to Moldova. All I wanted was to be with my mother and children. ${ }^{5}$

For some, the experience of trafficking is not a deterrent. Some are willing to continue risking their lives to find work abroad because there are no alternatives at home. Even victims who have been through a reintegration program insist that if they can't find a job at home, they would try to go abroad again. Inevitably, if there is no other source of income, a victim will risk braving the traffickers another time. The potential victim is less concerned about the risk of exploitation and abuse than with the primary goal of finding work. This desire for a better life-and, in the case of rural Moldovans, that means a minimal existence - will push people to try again and again until they succeed or die in their attempt to earn money.

\section{Turkey as a Destination Country}

Turkey has enormous economic potential, and even for an illegal immigrant earning USD 300-400 per month, that is better than the USD 50-100 they would be lucky to earn at home. It is easy to get to Turkey, which is a country that welcomes Russianspeaking tourists. Looking at the countries in the Black Sea region, Turkey stands out both in terms of political stability and economic potential. The per capita GNP in Tur-

5 IOM Turkey victim interview, 2005. 
key stands at USD 2,790 or almost five times that of Moldova, at USD 590. ${ }^{6}$ Despite the element of risk involved in working as an illegal immigrant, the potential victim of trafficking - who is already vulnerable and desperate - does not acknowledge the potential danger to herself during the recruitment process. Turkey's easy visa regime allows citizens of the former Soviet Union to buy a USD 10 visa upon arrival in Istanbul, a far more dignified procedure than the risk of becoming part of the refusal statistics (85 percent for Moldovan citizens) for applicants for Schengen visas to the EU States, or being forced to pay up to USD 4000 to a smuggler to gain access to the EU.

Victims of trafficking identified in Turkey generally claim that they had been recruited for work as nannies, care-givers, waitresses, sales assistants, and dancers. Indeed, most irregular Moldovan migrant workers in Turkey do work in these sectors, with domestic work and caring for the elderly being particularly common occupations. A recent report prepared for IOM Turkey cites the example of Gagauz women who voluntarily use illegal networks to "commute" to work as domestic servants in upperclass Istanbul homes. ${ }^{7}$ The women from this category who do fall victim to trafficking currently constitute the majority of cases assisted by IOM Moldova. These women come to Istanbul to work as domestic servants, but the places they frequent in Istanbul, particularly on their days off, may overlap with women who have come to do "buyingselling" ("alis-veris") of goods, and perhaps those who have come, knowingly or not, to engage in prostitution.

\section{The Role of Organized Crime in Human Trafficking}

Where there is demand, supply soon follows, and in the absence of effective control mechanisms there is ample opportunity for criminals to exploit the most vulnerable for potential profit. A trafficker can make a considerable amount of money in the trafficking business. The women trafficked for sexual exploitation that IOM Turkey has assisted handle between ten and forty clients each day. At USD 100-300 per client, the 266 women identified in 2004 by the Ministry of the Interior in Turkey as having been trafficked to work as sex workers have earned organized crime close to USD 300 million. That figure is based only on the women who have been rescued; if we assume that they may represent only some 10 percent of the total number of women trafficked for sexual exploitation, the actual figure becomes over USD 2 billion - and that is for Turkey alone.

Where does this money go? For the Department for Organized Crime at the Ministry of Interior in Turkey, human trafficking is a relatively new area of interest, and the degree of crossover between traffickers and organized crime is unknown. However, it is highly likely that human traffickers use the same routes and the same contacts to move women (and most likely men) as they do for drugs, weapons, and other items dealt in by organized crime. The money changing hands between criminal groups - whether they

6 GNP from 2003, World Bank Report.

7 Gagauzia is an autonomous region in Moldova where the majority of the population speaks a dialect of Turkish. 
are small family businesses or organized transnational networks - lines the pockets of people who are free to move between countries and continents to buy and sell their way into legal businesses to turn them into cover operations for money laundering. All the while, the trafficked women, men, and children are earning nothing compared to the income they generate. In many instances, the victims find themselves in a debt-bondage situation that they themselves don't fully recognize, because they believe that after they have repaid their debt to the trafficker they will begin earning income for themselves, as in the following case of a cook from Romania:

I was trained as a cook. I'm a Romanian citizen, and my family doesn't have enough to live on. I was promised work as a dancer in a casino. Before I left Romania, I signed a contract to work in Turkey. All the travel expenses and my boarding expenses were included in the contract. I came to Turkey, but when I arrived, I was told that I was liable for all the expenses. Everything: my housing, medical expenses, even the cigarettes that I smoked were included in my debt. In order to pay off my debt, I was told that I had to work as a bar girl. I refused. I felt it was a violation of my human rights. I wanted to return home. They didn't permit me to leave, and I didn't have enough money to return home. Before I left Romania, I had gone to the Turkish Embassy in Romania to get my Turkish visa. At the entrance, they were distributing brochures about the 157 trafficking victims' helpline number.

I remembered that the helpline had operators who could speak Russian and Romanian, and I right away called 157 and explained my problem. IOM and the Turkish police worked with me, and they rescued eight other Romanian women. Since the other women didn't want to return to their families empty-handed, they didn't want to return home and they refused to testify against the exploiters. They are still hoping that they will be able to pay off their debts and get a little money. IOM has helped me to return home to my country. I'd rather live on nothing than return to Turkey. ${ }^{8}$

\section{Profile of a Victim of Trafficking}

Who are those most at risk of being victims of trafficking? A disproportionate number of the victims identified in Turkey have also been victims of domestic violence or abuse in their countries of origin. Some also come from orphanages or boarding schools, or have mental disabilities. Up until July 2005, most trafficked persons rescued in Turkey were from eighteen to twenty-five years of age, with an increasing number of minors, which may point to a new trend. Most are recruited through a network of friends (figures from the Moldovan report show that more than half of those surveyed rated friends and family as their main source for reliable information on migration). Ukraine, the second main source country for victims of trafficking identified in Turkey, shows the same trend. Anya, a twenty-two-year-old from Ukraine, was recruited by a person from her home town, a friend of a friend. Anya was seven months pregnant when she was offered a job in Turkey for two months as a babysitter. Anya thought the money would come in handy for the baby, since both she and her husband were unemployed.

8 IOM Turkey victim interview, 2005. 


\section{The Trafficking Process}

Like Anya, most victims assisted by the IOM were recruited by direct contact. The proportion of female recruiters has increased; the conclusion we draw is that the traffickers feel that women are more likely to establish trust faster. Statistics from Turkey show a few cases of international trafficking for forced labor, but young Eastern Europeans and Central Asians are predominantly exploited for their sexual services.

Anya had two traffickers - a couple. She was sold into prostitution the day she arrived in Turkey. She was beaten when she tried to escape. Like Anya, 98 percent of the victims of trafficking assisted by the IOM were sexually exploited, with the remaining 2 percent exploited for forced labor. 80 percent had no freedom of movement, while 20 percent were allowed movement with supervision. For those that had already been recruited by traffickers in the source country, debt bondage is common. There is no freedom of choice, no choice of clients, and little chance for negotiation regarding safe sex.

Anya was earning her trafficker USD 2000 per day, but the work was too hard. She was also pregnant, and seven months into the pregnancy she hemorrhaged, and the baby was born prematurely in an elevator. The traffickers kept her baby and made Anya go back to work the next day. For fun they stuffed chewing gum down the baby's mouth to watch it turn blue. When the little girl died, she was placed in a box on the balcony. Anya herself was finally rescued in a police raid and was taken to the shelter for victims of trafficking in Istanbul to receive medical assistance and counseling.

\section{Prevention and how Victims of Trafficking See Themselves}

Despite very clear indicators that she was a victim, at the shelter in Istanbul Anya did not identify herself as a victim of trafficking; that is a label imposed on her by others, mainly organizations working in the field of counter-trafficking. Anya and the others at the shelter think of themselves as labor migrants that have been seriously exploited. Of course they feel that their rights have been violated, and they feel abused and cheated, but the initial reaction of the women is to identify themselves as labor migrants, never as victims of human trafficking.

Experience from Moldova underlines the above point. In 2003, the IOM bought the rights to the feature film Lilya 4-ever in order to show it to people like Anya who matched the profile of a trafficked victim (aged sixteen to twenty-five years, low level of education, unemployed) and to promote the anti-trafficking hotline. ${ }^{9}$ To our amazement, although the film increased understanding of the human trafficking phenomenon and built empathy for the victims, not a single viewer out of the 60,000 who saw the film thought of themselves as a potential victim of trafficking. However, close to 90 percent saw themselves - if anything — as a potential migrant, either irregular or regular. That influenced future information campaigns and led to a shift towards a more positive, empowering approach, including providing information on legal migration channels. The response was immediate, and there was a 200 percent increase in calls to the hotline (whose name was changed from the "trafficking" hotline to "information" hot-

9 Lilya 4-ever, dir. Lukas Moodysson, Memfis Film, Sweden (2002). 
line). What did we learn from this? In order to give people information they need, we must give them the information they want. Equally, it demonstrates the need for effective protection mechanisms in destination countries, as even the best prevention messages and information campaigns in source countries appear to have a limited impact. Turkey, in partnership with the IOM, has taken the additional step of incorporating information about its protection mechanisms into the source country campaigns.

\section{Applying Lessons Learned: Turkey's Response to Fighting Human Trafficking}

Taking note of the fact that human trafficking in Turkey is largely a cross-border phenomenon, the authorities have chosen to fight human trafficking by reaching out to potential victims before they leave their countries of origin. ${ }^{10}$ In coordination with IOM offices in Moldova, Ukraine, and Romania, Turkey is promoting the local helplines in the countries of origin as well as Turkey's own 157 helpline. The 157 helpline is open twenty-four hours a day, seven days a week, and is manned with Russian, Romanian, English, and Turkish-speaking operators. In its first six weeks of operation the Turkish helpline facilitated the rescue of nine victims of trafficking from Moldova and Ukraine.

A second activity in Turkey's regional response to fighting trafficking was to mobilize NGO networks in Moldova and Ukraine to distribute small flyers. The flyers are printed in Russian, Romanian, Turkish, and English. They contain a positive and empowering message in order to attract the attention of the potential victim who believes that Turkey offers a chance for her to improve the lives of her family members back home. Readers will reject any campaign that is perceived as negative, frightening, or not matching expectations about life in Turkey. The flyers are distributed across the target countries, and also at the main seaports and airports in Ukraine. Upon arrival in Istanbul, Antalya, and Trabzon, Turkish immigration officials hand the same flyer to members of our target group. At the same time, an advertising campaign in the four languages at the ports of entry is supported by billboards, posters, and stands in the most frequented areas of the arrival halls.

Since most victims of trafficking enter Turkey legally on tourist visas, this is the one chance Turkey has to reach out to the potential victims of trafficking, giving them the phone number of the helpline and informing them of the organizations in Turkey that can help them if they are in trouble. Establishing trust from the outset is important; if there is trust from the beginning, then the victim is more likely to collaborate with law enforcement agencies to prosecute the trafficker after being rescued. Turkey has realized the need for a regional effort to fight human trafficking within its own borders, and is in the forefront of destination countries in developing such innovative approaches.

Although much remains to be done, Turkey has made giant strides forward in fighting human trafficking, with the number of victims identified tripling in the last three

10 Internal trafficking also exists. Contrary to human smuggling, trafficking in persons does not necessarily entail crossing an international border - it is a crime against a person, not against a state. 
years (instead of reflecting an increase in the rate of trafficking activity, this is more reflective of improved enforcement efforts - more victims are being helped). Turkey also acknowledges the problem of internal trafficking: 27 of the 266 women identified last year as victims of human trafficking were Turkish nationals. A rapid assessment by the IOM of internal trafficking in Turkey will be finalized by the end of 2005 .

With the entering into force of the new penal code in Turkey, videotaped testimonials and stiffer penalties for traffickers are now possible. The code also allows for assets to be seized. Training for law enforcement officers continues, resulting in improved capacity for law enforcement agencies to differentiate between human trafficking, migrant smuggling, and other forms of irregular migration. This rights-based training has been extended to the armed forces, and in 2005 representatives of the Turkish military, through the Partnership for Peace initiative, have toured most of Eastern Europe and the CIS to conduct training programs for law enforcement, police, and military personnel on human trafficking, terrorism, and migrant smuggling. This initiative is aimed at building bridges between source and destination countries that will support anti-trafficking activities in the future, and further sensitize source countries to the links between trafficking and other forms of organized crime, including money laundering, in order to target the criminals where it will hurt them the most - their bank accounts.

\section{The Human Cost of Trafficking}

For transition economies like Moldova, losing 39 percent of the nation's working-age population to migration - and human trafficking - also means losing those members of society that are most needed for the economic development of their country. Most migrants report experiencing harsh working conditions, where they are often exposed to serious health risks. In the case of victims of human trafficking, merely the short-term medical, psychological, legal assistance, and other associated costs average roughly USD 2000 per beneficiary. But this cost does not include the life-long counseling needed to recover from the psychological trauma, or the fact that only 30 percent of victims of human trafficking recover sufficiently to lead normal lives. Of equal concern are the children of the victims who, because of their dysfunctional family structure, are in the highest-risk group for being trafficked themselves. Lives lost, collapsed societal and family structures, and non-productive citizens are a heavy burden for a country in transition.

Another human cost of migrant smuggling is the damage that is done to the image of migrants, and an increase in xenophobia. Up until now, unmanaged migration flows in destination countries have resulted in a perception by the general public that migrants are to blame for the growth in organized crime. But migration is an issue that affects us all; it is and always has been a natural human phenomenon. That is why it cannot be left to criminals to manage migration for us. 


\section{The Way Forward: Strengthening Cooperation on Migration Management in the Black Sea Region}

Statements from victims rescued in Turkey support the need for a regional response to human trafficking. Their reluctance to identify themselves as victims of trafficking, seeing themselves rather as labor migrants, and their determination to migrate despite being made aware of the risks they face, continues to pose an enormous challenge to the international community. The generally accepted approach to combating human trafficking - incorporating and emphasizing the three "Ps" of prevention, protection, and prosecution - may be the best way to assist the victims and address the immediate and egregious human rights violations that define the trafficking phenomenon, but it does nothing to break the cycle of empty promises, dashed hopes, and ruined lives. If we truly have concern for Anya from Ukraine and the thousands of other victims of human trafficking, then we must begin to listen to them more closely and try to address their immediate need to earn a living and provide for their children and families.

The ideal long-term solution, of course, is economic development in the source countries, but in the meantime - and with the legacy of almost two decades of empty promises-people will continue to choose migration as the quickest and easiest way toward bettering their lives. For that reason, there must be a mechanism in place to enable states to better manage these migration flows and counteract the influence of criminal groups. If no effective measures are in place to protect migrants and safeguard the interests of the source and destination states, organized crime is free to maneuver in the resulting vacuum. Turkey's recent efforts to reach out to potential victims of human trafficking have proven to be immensely successful, underscoring the value of a regional approach to reducing the risks of irregular migration. The challenge now is to be equally bold in establishing a dialogue between the states in the Black Sea region as a means toward managing migration in a way that provides economic and social benefits for both the source and destination countries, while countering human rights abuses and transnational organized crime. By taking this course, states will be recognizing what the victims of trafficking are telling us: that in order to truly protect their human rights, ultimately we must provide them with an opportunity to earn a living in safety and with dignity. 